\title{
Identification des produits tinctoriaux de deux soieries médiévales à fond de losanges liserés et bandes de samit façonné
}

Witold Nowik

\section{OpenEdition}

Journals

Édition électronique

URL : https://journals.openedition.org/tc/340

DOI : $10.4000 /$ tc.340

ISSN : 1952-420X

Éditeur

Éditions de l'EHESS

Édition imprimée

Date de publication : 1 janvier 2000

ISSN : 0248-6016

Référence électronique

Witold Nowik, «Identification des produits tinctoriaux de deux soieries médiévales à fond de losanges liserés et bandes de samit façonné », Techniques \& Culture [En ligne], 34 | 2000, mis en ligne le 26 octobre 2005, consulté le 29 septembre 2022. URL : http://journals.openedition.org/tc/340 ; DOI : https://doi.org/10.4000/tc.340

Ce document a été généré automatiquement le 29 septembre 2022.

Tous droits réservés 
Identification des produits tinctoriaux de deux soieries médiévales à fond de losanges liserés et bandes de samit façonné Witold Nowik 